Ankara Ecz. Fak. Mec.

12. 121 (1982)
J. Fac. Pharm Ankara

12. 121 (1982)

\title{
Sık Olarak Zehirlenmelere Neden Olan İlaçların, XAD-2 ile İdrardan İzolasyon Koşullarının Araştirilmasi ve Bir Toksikolojik Analiz Tarama Yönteminin Geliştirilmesi*
}

Investigations of Isolation Conditions of Drugs from Urine with XAD-2 Resin in Cases of Acute Poisoning and a Development of a Toxicological Screening Test

G İ R İ Ş

Zehirlenmeler tüm dünya ülkelerinde, gerek hastaneye yatış nedeni, gerekse ölüm nedeni olarak önemli bir yer tutmaktadirlar. Özellikle, kimyasal maddelerin her alanda yaygın olarak kullanıldı̆̆ endüstrileşmiş ülkelerde her yıl çok sayıda zehirlenme olayı oluşmaktadır. Örneğin, A.B.D.'nde her yıl yaklaşık 5 milyon zehirlenme olayı olduğu tahmin edilmekte, bunun da yaklaşık 5 bininin ölümle sonuçlandığ 1 bildirilmektedir (1). Ülkemizde de, Sağlık ve Sosyal Yardım Bakanlığı istatistiklerine ve bu konuda yapılan bazı araştırmalara göre gerek kaza, gerekse intihar amaciyla oluşan zehirlenme olayları, sağlık sorunları arasında önemli bir yer tutarlar. Sağlık ve Sosyal Yardım Bakanlığı tarafından yayınlanan Türkiye Sağlık İstatistiği Yıllı̆̆ı'na göre 1978 yılında Türkiye'deki yataklı tedavi kurumlarında kaza sonucu zehirlenme nedeni ile yatarak tedavi gören hastaların sayısı 23967'dir. Bu olgulardan 699'u ise ölümle sonuçlan-

Redaksiyona verildiği tarih: 30 Aralık 1982.

* Ecz. Asuman Karakaya'nın "Türkiye'de Sık Olarak Zehirlenmelere Neden Olan İlaç ve Pestisillerin XAD-2. ile İdrardan İzolasyon Koşullarının Araştırlması ve Bir Toksikolojik Analiz. Tarama Yönteminin Geliştirilmesi" isimli doktora tezinin bir bölümünden özetlenmiştir. Sinav tarihi: Nisan 1982.

\footnotetext{
** Farmasötik Toksikoloji Ana Bilim Dalı, Eczacılık Fakültesi, Ankara Üniversitesi
} 
miştır (2). Yatarak tedavi olmayan veya bu kurumlara ulaşamayan olguların varlığı da düşünüldügüude sorunun boyutu daha da kolaylıkla anlaşılabilir.

Dünya Sağlık Örgütü hastalık nedenlerini 150 olarak saptamıştır. Yine ülkemizde 1978 yılında kaza sonucu zehirlenmeler hastaneye yatma nedeni olarak 18., hastaneye yatan hastalar arasinda ölüm nedeni olarak da 15 . sıradadır (2).

Çeşitli Dünya ülkelerinde zehirlenmeler ile ilgili istatistiksel çalışmaların sonuçları, zehirlenme olaylarının bazı ortak özellikleri olduğunu göstermektedir. Bu özellikler, kaza sonucu zehirlenmelerin büyük çoğunluğunun 5 yaş altındaki yaş grubunda görüldüğü (3-5), zehirlenme etkeni olarak ilaçların ilk sırada yer aldı̆̆ 13,6$)$, ilaç zehirlenmelerinin ise büyük bir bölümünü, barbitürat, benzodiazepin, salisilat, fenotiazin, trisiklik antidepresan ilaç gruplarının oluşturduğu (5,7-12) şeklinde özetlenebilir.

Türkiye'de de zehirlenmelerin istatistiksel değerlendirilmesi ile ilgili yapılan bazı bölgesel araştırmalara göre, gerek kaza zehirlenmeleri (13), gerekse intihar amaçli (14) zehirlenmelerde ilaçlar 1. sırada yer almaktadır. 1979 yılında yapılan bir araştırmada İzmir'de resmi yataklı tedavi kurumlarına gelen zehirlenme olguları incelenmiş, ilaç zehirlenmelerinin 12 yaş üstü zehirlenme olgularında, \% 69 gibi büyük bir oranla, 0-12 yaş arası zehirlenme olgularında ise $\% 62$ oranla 1 . sırada yer aldı̆̆ 1 bildirilmiştir (15).

Hastanelerde akut zehirlenme başvurularında ilk yardım ve belirtilere yönelik tedavinin yanısıra, zehirlenme etkeninin toksikolojik analizlerle tayini ve böylece tedaviye analitik bir tanımla yardımcı olunması gerekmektedir. Bu amaçla yapılacak toksikolojik analizler, hızlı, duyarlı, basit ve ucuz gereçlerle yapılabilen ve hastane başvuruları gözönüne alınarak taranacak zehirlenme etkeni sayısı sınırlandırılmış tarama testleri olmalıdır (16-19).

Yukarıda belirtilen özelliklere sahip bir toksikolojik analiz tarama yöntemi kurmayı amaçlayan çalışmamızda 21 ilaç test kapsamına alınmıştır. Tarama testinde, zehirlenme etkeninin idrardan izolasyonu için, Amberlit XAD-2 reçinesi ile ekstraksiyon yönteminin, nitel analiz içinde, ince tabaka kromatografisi (İ.T.K.) yönteminin kullanılması amaçlanmıştır. 
Çalışmamız aşağıdaki bölümlerde gerçekleştirilmiştir:

1- Ankara'da acil servis hizmet kapasitesi yüksek olan Sağlık ve Sosyal Yardım Bakanlığı Ankara Numune Hastanesi, örnek hastane seçilerek, bir yıllık acil servis başvurularının taranması ve akut zehirlenme olaylarının değerlendirilmesi.

2- Daha önce bu konuda yapılan çalışmalar ve çalışmamızın ilk bölümünde elde edilen veriler gözönüne alınarak seçilen 21 ilacı kapsayan bir tarama yönteminin kurulması.

a) Tarama testi kapsamındaki ilaçların reçinede adsorpsiyon ve elüsyon koşullarının incelenerek Amberlit XAD-2 ekstraksiyon yönteminin standardizasyonu ve kurulan ekstraksiyon yöntemi ile nicel verim tayini çalışmaları.

b) Test kapsamındaki 21 ilacın Amberlit XAD-2 ile ekstraksiyondan sonra tanınmalarını sağlayan İ.T.K.'ya dayalı analiz yönteminin geliştirilmesi.

\section{MATERYAL ve YÖNTEM \\ MATERYAL}

Kullanilan aletler: Gaz kromatograf (Packard-Becker Model 419), U.V. spektrofotometresi (Pye-Unicam SP 1700), İ.T.K. takımı (Desega), musluklu cam kolonlar (130 x $10 \mathrm{~mm})$.

Kimyasal maddeler: Çalışmamızda kullandı̆̆ımız tüm kimyasal maddeler analitik saflıktadir.

İlaç standartları: Fenobarbital (BDH-İngiltere), pentobarbital sodyum (Abbott-Türkiye), butalbital (Sandoz-Türkiye), glutetimid, imipramin HCI (Ciba-İsviçre), metakualon (Merck-B. Almanya), nitrazepam (F. Hoffmann LaRoche-İsviçre), diazepam, desipramin HCI (Deva-Türkiye), klordiazepoksid HCl, medazepam, amitriptilin $\mathrm{HCl}$ (Roche-Türkiye), okzazepam (Dr. Karl Thomac Gmb. H-B. Almanya), klorpromazin HCI (Eczacıbaşı-Türkiye), meprobamat (Atabay-Türkiye), kodein fosfat ( $\mathrm{Mc}$ farlan Smith-İngiltere), etil morfin HCI (Knoll-B. Almanya), morfin HCI (SandozIsviçre), aspirin (Brothers Chemical-A.B.D.), amfetamin fosfat (Hüsnü Arsan-Türkiye), Amberlit XAD-2 (Eastman Kodak-A.B.D.) firmalarından sağlandı. 
Y Ö N T E M

1- Hastane acil servis başvurularında zehirlenme olgularının değerlendirilmesi:

Acil servis hizmet kapasitesi yüksek olduğu için örnek hastane olarak seçtiğimiz Sağlık ve Sosyal Yardım Bakanlığı Ankara Numune Hastanesi Acil Servisi'ne 1 Ocak 1980 ve 31 Aralı 1980 tarihleri arasında başvuruda bulunanlara ait hasta kayıt defterleri tarand. Besin zehirlenmeleri dişında, tüm akut zehirlenme olguları kaydedilerek; dirild1.

a) Zehirlenme olguları, zehirlenme etkenlerine göre sınıflan-

b) İlaç zehirlenme olguları içerisinden, nedeni belli olanların ilaç gruplarına göre dağılımı yapıldı.

c) İlaç zehirlenmeleri ve diğer zehirlenmelerin yaşa göre da$\breve{g}$ 1lımları istatistiksel olarak değerlendirildi.

2- Tarama yönteminin kurulmasına ait çalışmalar:

a) Reçinenin hazırlanış1: Kullanılmadan önce reçine 1:1 oranında 2-3 hacim* metanol/ su karışımı ile 4-5 kez yıkandi. Daha sonra metanolü tümüyle uzaklaştırmak için 8-10 kez aynı hacim distile su ile yıkandı. Reçine, ağzı kapalı cam bir kapta, distile su içerisinde $+4^{\circ} \mathrm{C}^{\prime} \mathrm{de}$ sakland.

b) Çeşitli pH'larda XAD'deki adsorpsiyon veriminin U.V. spektrofotometrik yöntemle hesaplanması: Adsorpsiyon verimlerinin hesaplanması batch yöntemi (20) uygulanarak yapıldı. 5 ayrı pH'da adsorpsiyon verimleri spektrofotometrik olarak ölçüldü. p H - \% adsorpsiyon eğrileri çizildi ve neticede XAD-2 ile adsorpsiyon için en uygun pH, 6.5 olarak seçildi.

c) İlaçların İ.T.K.' da nitel tayinleri: Referans standart olarak seçilen 21 ilacın metanoldeki \% 0.1'lik çözeltileri hazırlandı.

Developman çözücüsü olarak etil asetat/metanol/amonyak (85:10:5) (21) çözücü sistemi, denenen diğer çözücü sistemleri içersinde tarama testimiz kapsamındaki 21 ilacı en iyi ayırabilen sistem olduğu için seçildi.

* Reçine yatak hacmi, hacim olarak ifade edilmiştir. 
İlaç örnekleri $0.25 \mathrm{~mm}$ kalınlığında silikajel-G plaklara, 5-10-20 ul uygulanarak, daha önceden çözücü ile doyurulmuş tanklara yerleştirildi. Çözücü $12 \mathrm{~cm}$ yükselince plak tanktan çıkarılıp oda sıcaklığında kuruldu. Sonra aşă̆ıdaki renk belirteçleri (22) birbiri ard1sıra uyguland 1 ve her bir işlemden sonra beliren lekeler saptandi.

Amonyak buharlarının tamamen plaktan uçurulması amaciyla etüvde $75^{\circ} \mathrm{C}^{\prime} \mathrm{de} 10$ dakika tutuldu ve sonra U.V. 1 şı̆̆ 1 altında incelendi. Ninhidrin belirteci püskürtülüp, U.V. 1şı̆̆ı $(254 \mathrm{~nm})$ altında 2 dakika bekletildi. Civa sülfat belirteci ve sonra difenilkarbazon belirteci püskürtüldü. Plaklar $75^{\circ} \mathrm{C}$ lik etüve yerleştirilerek 2 dakika bekletildi. Etüvden çıktıktan sonra U.V. 1şı̆̆ı (254 nm) altında incelendi. Birbirini izleyerek iyodoplatinat, dragendorf ve furfural belirteçleri püskürtüldü. Birbirini izleyen belirteç püskürtmeleri sırasında plakların kurutulması koşuluna dikkat edildi.

d) İdrar örneklerinin hazırlanışı: Yöntem kurma çalışmalarında, $10 \mu \mathrm{g} / \mathrm{ml}$ konsantrasyonda referans standart ilave edilerek hazırlanmış, normal bireylerden alınan idrar örnekleri kullanıldı. İdrar örnekleri, kullanılmadan önce $2500 \mathrm{rpm}$ 'de 5 dakika santrifüj edilerek, berrak kısımdan 20'şer ml alındı.

e) İlaçların idrardan XAD-2 ile ekstraksiyonu: pH'sı 6.5'a ayarlanan $20 \mathrm{ml}$ idrar, kuru ağırlık olarak 2 gr'a karşılık yaş XAD-2 içeren ve daha önceki çalışmamızda (23) şekli gösterilen cam kolondan, akış hızı $1 \mathrm{ml} /$ dakika olacak şekilde akıtıldı. Kolonda kalan sulu kısım su trompu ile sağlanan vakum yardımıyla emildi. Elüsyon, kolondan 25'er ml ve $1 \mathrm{ml} /$ dakika hizla etil asetat/ 1,2-dikloroetan $(3: 2)$ çözücü sistemi geçirilerek yapıldı. Ekstrakt $0.1 \mathrm{ml}$ metanolde çözülüp yukarıda anlatıldı̆̆ şekilde İ.T.K.'ya uygulandı [3 ayrı çözücü sistemi ile, ekstraktların yaklaşık verimleri ve idrardan gelen girişimler, İ.T.K.'da incelenerek bunların arasından en uygun elüsyon çözücüsü olarak etil asetat/1,2-dikloroetan (3:2) seçildi].

f) Ekstraksiyon veriminin gaz-sıvı kromatograıik yöntemle nicel tayini: Seçilen pH'da ve seçilen elüsyon çözücüsü ile ekstraksiyon veriminin nicel tayini için asit bir ilaç olan butalbital ve bazik bir ilaç olan diazepam seçildi. Butalbitalin ekstraksiyon veriminin tayini için, alev iyonlaştırma dedektörü (FID), sabit faz olarak \% 3 SE-30, iç standart olarak glutetimid kullanıldı. Diazepamın ekst- 
raksiyon veriminin tayini için FID, sabit faz olarak \% 3 SE-30, iç standart olarak okzazepam kullanıldı.

\section{B U L G U LA R}

1- Sağlık ve Sosyal Yardım Bakanlı̆̆ 1 Ankara Numune Hastanesi Acil Servis Bölümüne 1 Ocak 1980 ve 31 Aralık 1980 tarihleri arasında yapılan başvuru sayısı 28655, zehirlenme nedeni ile başvuru sayıs1 1428'dir (\% 4.98).

Zehirlenme olgularının zehirlenme etkenlerine göre dağılımı Şekil 1'de gösterilmiştir.

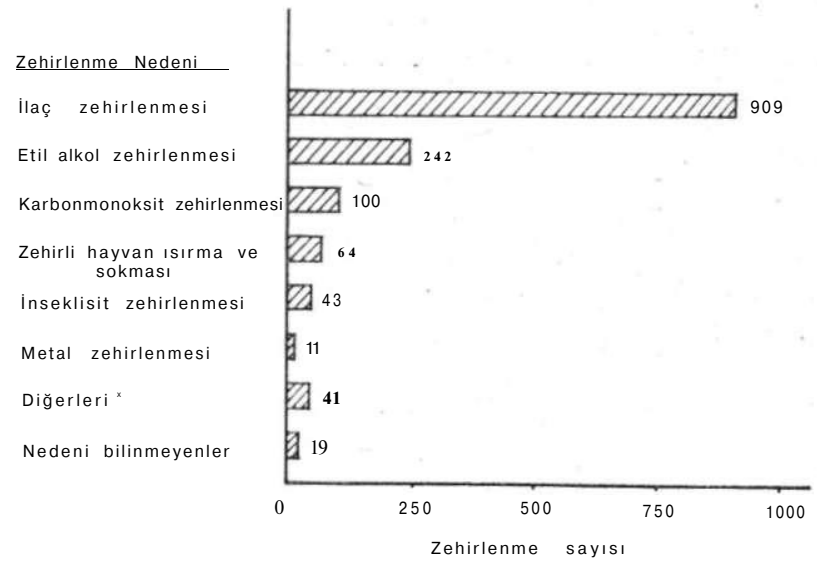

Şek. 1. Zehirlenme Olgularının Zehirlenme Etkenlerine Göre Dağılımı.

* Evlerdeki temizlik malzemeleri, zehirli mantarlar gibi etkenler.

908 ilaç zehirlenme olgusunda, kayıtlı olan 401 ilacın değerlendirilmesi yapılarak bu olgularda ilaçların dağılımı Tablo I'de gösterilmiştir.

Tablo 1. İlaçlarla Zehirlenme Olgularında İlaçların Dağılımı

\begin{tabular}{|l|r|}
\hline Barbitüratlar & $\mathbf{1 4 3} \quad \mathbf{( 1 0 4}$ 'ü optalidon) \\
Benzodiazepinler & 98 \\
Analjezikler & $\mathbf{8 0}$ (44'ü aspirin) \\
Antibiyotikler & $\mathbf{1 3}$ \\
Diğer ilaçlar & 67 \\
\hline Toplam & $\mathbf{4 0 1}$ \\
\hline
\end{tabular}


ilaç zehirlenme olguları ve diğer zehirlenme olgularının yaşa göre dağılımları Şekil 2'de gösterilmiştir.

2- 5 ayrı pH'da adsorpsiyon verimi çalışmaları sonucu, XAD-2 ile adsorpsiyon için optimum pH, 6.5 olarak seçilmiştir. Şekil 3'te fenobarbital, pentobarbital, allobarbital, butalbital ve aspirinin, Şekil 4'de kodein, etil morfin ve morfinin, Şekil 5'te klorpromazin, amfetamin, amitriptilin, desipramin ve imipraminin $\%$ adsorpsiyon - pH eğrileri görülmektedir.

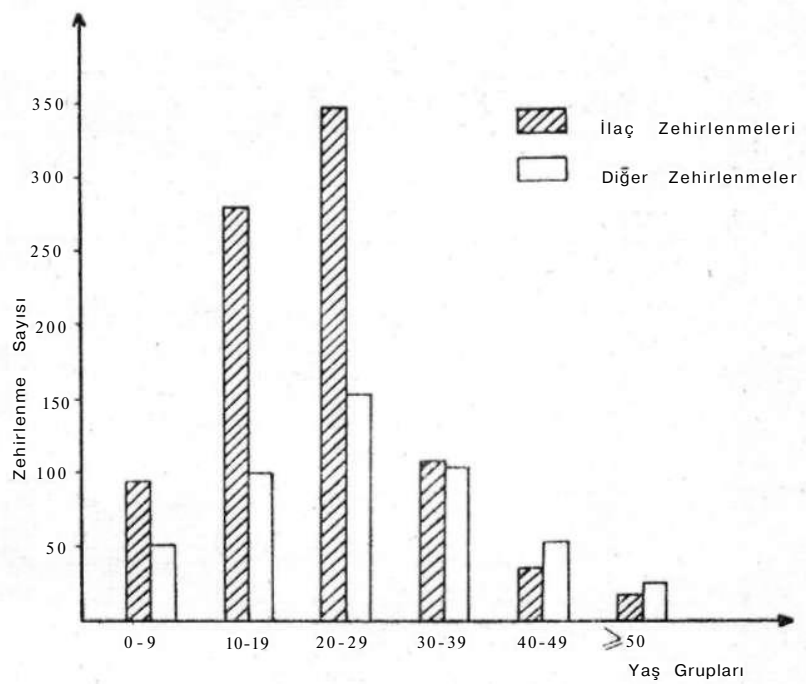

Şek. 2. İlaç ve Diğer Zehirlenme Olgularının Yaşa Göre Dağılımı.

Çalışmamız kapsamındaki ilaç referans standartlarının silikajel-G $(0.25 \mathrm{~mm})$ üzerinde, yöntemde kullanılan çözücü sistemi ile verdikleri Rfdeğerleri ve renk belirteçleri ile verdikleri renkler Tablo II'de gösterilmiştir.

Ekstraksiyondan sonra İ.T.K.'da yapılan yaklaşık verim tayini çalışmalarında, etil asetat/metanol (1:1) ve kloroform/izopropanol (3:1) elüsyon çözücüleri ile iyi verim elde edilmesine karşın, idrardan gelen girişimler fazla olduğu için, hem verimi yüksek, hem de daha temiz ekstrakt verebilen etil asetat/ 1,2 - dikloroetan (3:2) çözücü sistemi, elüsyon çözücüsü olarak seçilmiştir. 


\section{Nevin VURAL ve Asuman KARAKAYA}

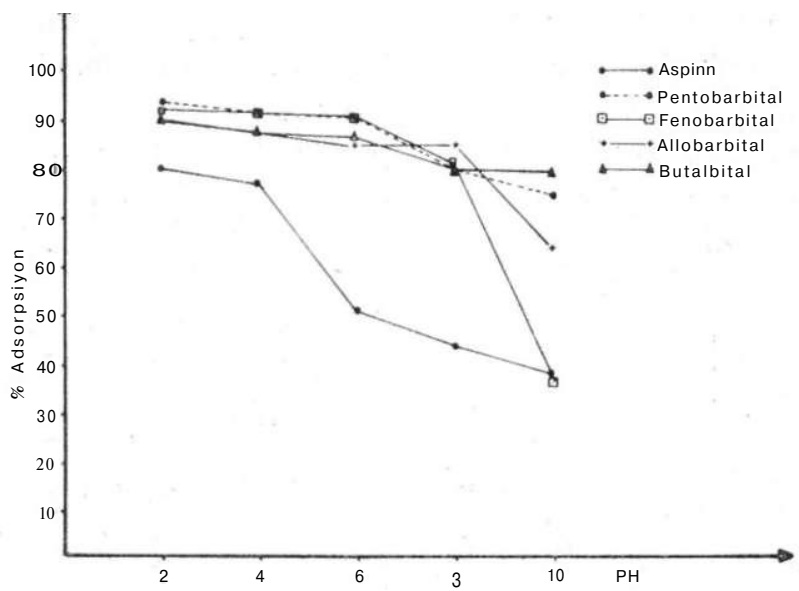

Şek. 3. Fenobarbital, Pentobarbital, Allobarbital, Butalbital ve Aspirinin \% Adsorpsi yon-pH Eğrileri.

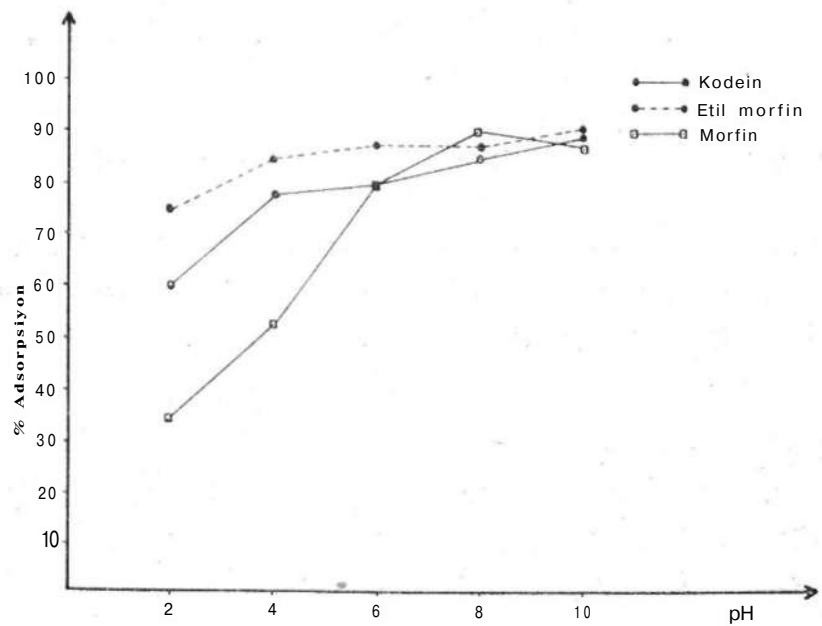

Şek. 4. Kodein, Etil morfin ve Morfinin \% Adsorpsiyon-pH Eğrileri. 


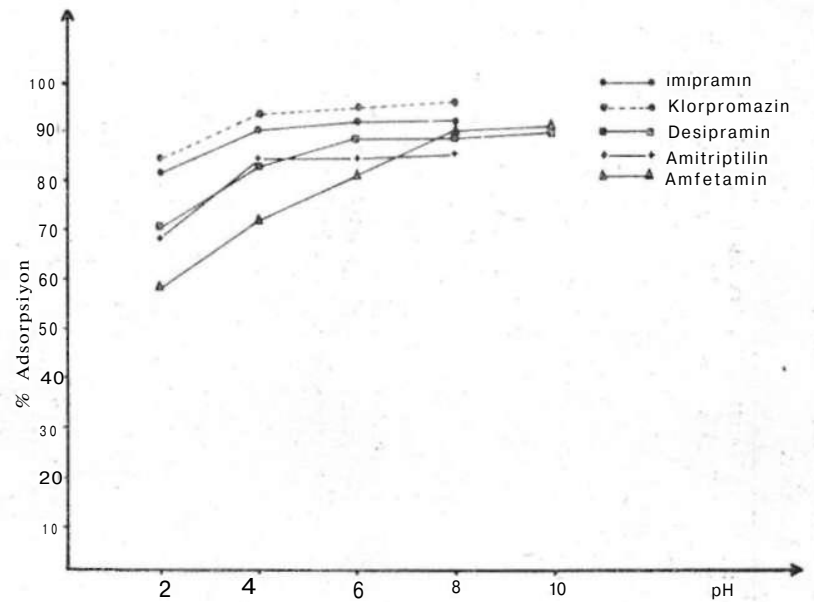

Şek. 5. Klorpromazin*, Amfetamin, Amitriptilin, Desipramin* ve İmipraminin* \% Adsorpsiyon-pH Eğrileri.

*pH 10'da yeteri derecede çözünmedikleri için klorpromazin, amitriptilin ve imipraminin pH 2,4, 6 ve 8'deki adsorpsiyon verimleri ölçülmüştür.

Butalbital ve iç standart olarak kullanılan glutetimidin gazsıv1 kromatografisi FID'deki kromatogramı Şekil 6'da gösterilmiştir. Belirtilen kromatografik koşullarda alıkonma zamanı butalbital için 3.0 dakika, glutetimid için 5.2 dakika olarak saptanmıştır. Diazepam ve iç standart olarak kullanılan okzazepamın gaz sıvı kromatografisi-FID'deki kromatogramı Şekil 7'de gösterilmiştir. Belirtilen kromatografik koşullarda alıkonma zamanı diazepam için 6.9 dakika, okzazepam için 5.0 dakika olarak saptanmıştır. Butalbital ve diazepamın seçilen elüsyon çözücüsü kullanılarak ekstraksiyon verimlerinin nicel tayini için gaz sıvı kromatografisi-FID'de çizilen kalibrasyon eğrilerinin doğru denklemleri ve ilişki katsayıları aşağıda gösterilmiştir.

$$
\begin{aligned}
& \begin{array}{llll} 
& \underline{y}=\mathrm{ax}+\mathrm{b} & \text { İlişki katsaỵıs1 } \\
\cline { 2 - 3 } & \mathrm{y}=0.42 \mathrm{x}-0.20 & 0.9659
\end{array} \\
& \text { Diazepam/ okzazepam y }=2.64 \mathrm{x}-0.41 \quad 0.9881
\end{aligned}
$$

Yukarıda anlatılan XAD-2 ekstraksiyon yöntemi ile butalbitalin ekstraksiyon verimlerinin $(n=5)$ ortalaması $\% 79.9 \pm 1.1$, 
Tablo II. İlaçların, Silikajel-G (0.25 mm) Adsorban Üzerinde, Etil esetat/ Metanol/ Amonyak (85:10:5) Çözücü Sistemi ile Verdikleri Rf Değerleri ve Renk Belirteçleri ile Verdikleri Renkler.

\begin{tabular}{|c|c|c|c|c|c|c|c|}
\hline İlaç & $\mathrm{Rf}$ & U.V. & $\begin{array}{c}\text { Ninhidrin/ } \\
\text { U.V. }\end{array}$ & $\begin{array}{c}\text { Civa sülfat/ } \\
\text { Difenilkarbazon }\end{array}$ & $\begin{array}{c}75^{\circ} \mathrm{C} 1 \mathrm{~s} 1 / \\
\mathrm{u} . \mathrm{v}\end{array}$ & $\begin{array}{c}\text { İyodoplatinat } \\
\text { Dragendorf }\end{array}$ & Furfural \\
\hline Fenobarbital & 0.26 & & & Mor & - & & \\
\hline Pentobarbital & 0.50 & - & - & Mor & $\overline{-}$ & & - \\
\hline Allobarbital & 0.35 & - & - & Mor & - & & \\
\hline Butalbital & 0.42 & - & - & Mor & - & - & - \\
\hline Glutetimid & 0.78 & - & - & Mor & & & \\
\hline Metakualon & 0.79 & - & - & - & - & Koyu sar1 & - \\
\hline Nitrazepam & 0.66 & - & - & - & Floresans & Kizıl kahverengi & - \\
\hline Diazepam & 0.76 & - & - & - & Floresans & Kiz1l kahverengi & - \\
\hline Klordiazepoksid & 0.57 & - & - & $\overline{-}$ & Floresans & Kizil kahverengi & - \\
\hline Medazepam & 0.80 & - & - & - & Floresans & Kizıl kahverengi & - \\
\hline Okzazepam & 0.50 & - & - & - & Floresans & Kızıl kahverengi & - \\
\hline Klorpromazin & 0.80 & - & $\widehat{\text { Sar1 }}$ & Pembe & Koyu pembe & Siyah & - \\
\hline Meprobamat & 0.64 & - & - & - & - & - & Siyah \\
\hline Kodein & 0.46 & - & - & - & - & K1rmiz1 viyole & - \\
\hline Etil morfin & 0.48 & - & - & - & - & Viyole & - \\
\hline Morfin & 0.26 & - & - & - & - & Koyu mavi & - \\
\hline Aspirin & 0.08 & Floresans & - & - & - & - & - \\
\hline Amfetamin & 0.52 & - & Pembe & Pembe & - & Kahverengi & - \\
\hline Amitriptilin & 0.80 & - & - & - & - & Açık kahverengi & _ \\
\hline Desipramin & 0.56 & - & - & Açık yeşil & Açık yeşil & Kizıl kahverengi & - \\
\hline Imipramin & 0.77 & - & - & Açık yeşil & Aç1k yeşil & Kizıl kahverengi & - \\
\hline
\end{tabular}


Sabit faz : \% 3 SE-30

Dedektör : FID

Taşıyıcı gaz (azot) akış hızı : $38 \mathrm{ml} /$ dakika Hidrojen akış hızı: $30 \mathrm{ml} /$ dakika Hava akış hızı: $\mathbf{3 0 0} \mathrm{ml} /$ dakika Fırın sıcaklığı: $172{ }^{\circ} \mathrm{G}$

Enjeksiyon giriş sıcaklığ $\breve{l}_{1} \mathbf{2 2 0}{ }^{\circ} \mathrm{C}$ Dedektör sıcaklı̆̆

Att : 16

Kaydedici hızı : $\mathbf{0 . 5} \mathrm{cm} /$ dakika

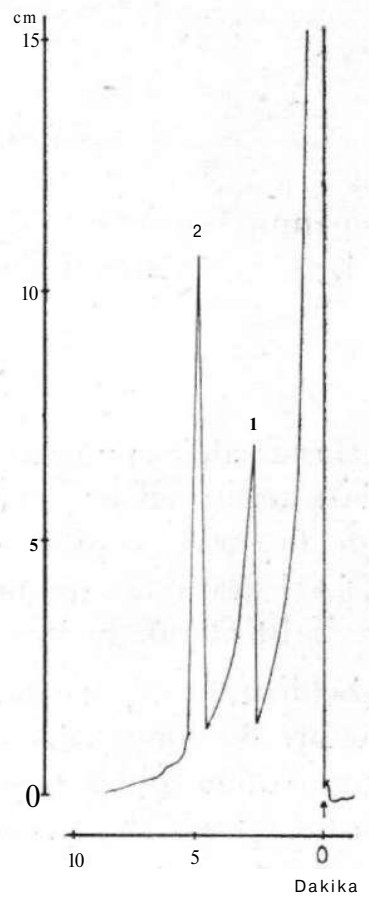

Şek. 6. Butalbital ve Glutetimidin Gaz Sivı Kromatografisi-FID'deki Kromatogramı 1. Butalbital (400 $\mathrm{ng})$

2. Glutetimid (200 ng)

Sabit faz: \% 3 SE-30

Dedektör: FID

Taşıyıcı gaz (azot) akış hızı: $50 \mathrm{ml} /$ dakika Hidrojen akış hızı: $30 \mathrm{ml} /$ dakika

Hava akış hızı: $300 \mathrm{ml} /$ dakika

Firın sicaklığ ${ }_{1}: \quad 220^{\circ} \mathrm{C}$

Enjeksiyon giriş sıcaklığ 1 : $\mathbf{2 5 0}^{\circ} \mathrm{C}$

Dedektör sıcaklığı: $\quad \mathbf{2 5 0}^{\circ} \mathrm{C}$

Att: $\mathbf{1 6}$

Kaydedici hızı: 0.5 cm/dakika

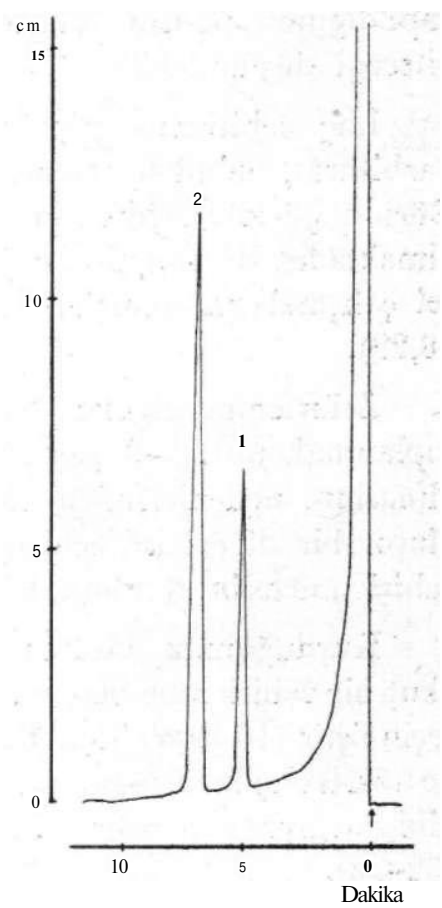

Şek. 7. Diazepam ve Okzazepamın Gaz Sıvı Kromatografisi-FID'deki Kromatogramı 1. Okzazepam (200 $\mathbf{n g})$

2. Diazepam (200 ng) 
diazepamin ise ekstraksiyon verimlerinin ortalamasi $(n=5) \%$ $73.4 \pm 3.5$ olarak bulunmuştur.

SONUÇ ve TARTIŞMA

Hastanede yaptı̆̆ımız çalışmaların bulgularına göre, zehirlenme olguları acil servis başvurularının \% 4.98'ini kapsamaktadır. İngiltere'de bu oran, çeşitli hastanelerde yapılan araştırmalarda \% 7.0 - \% 11.1 arasında saptanmıştır $(24,25)$. A.B.D.'nde ise ülke genelinde \% 10 olarak bildirilmektedir (1).

Zehirlenme olgularının \% 63.6'sını ilaç zehirlenmeleri oluşturmaktadır. Bu sonuç, ülkemizde de ilaç zehirlenmelerinin diğer ülkelerde olduğu gibi zehirlenme nedenlerinin ilk sırasında yer aldığ konusunda bir fikir verebilmektedir.

Pestisit zehirlenmeleri 5. sırada yer almaktadir. Ancak ülkemizde zaman zaman kırsal kesimlerde büyük sayıda pestisit zehirlenmeleri bildirilmektedir $(26,27)$. Tüm ülkeyi kapsayan bir çalışma yapıldı̆̆ında pestisit zehirlenmelerinin daha üst sıralarda yer alabileceği düşünülebilir.

İlaç zehirlenme olgularından, adı kayıtlı 401 ilacın 143'ünü barbitürat, 98'ini benzodiazepin grubundan ilaçlar oluşturmaktadir. Görüldüğ̈ gibi zehirlenme etkeni olarak barbitüratlar ilk sırada yer almaktadır. Bu bulgular, diğer ülkelerde bu konuda yapılmış istatistiksel çalışmaların sonuçları ile uyum göstermektedir $(5,7-10,12,24,25$, $28,29)$.

Zehirlenme olguları daha çok 20-29 ve 10-19 yaş gruplarında toplanmaktadır. 0-9 yaş grubunda zehirlenmelerin daha az sayıda olmasının nedenlerinden biri örnek hastanemizin genel bir hastane oluşu, bir diğeri ise zehirlenme olgularının kaza ve intihar amaçlı zehirlenmelerin tümünü kapsamasıdır.

Kurduğumuz tarama yöntemimizde biyolojik örnek olarak, akut bir zehirlenme olayında hastadan kolayca alınabildiği için, idrar seçilmiştir $(16,19,30,31)$. Tarama töntemimiz, 21 ilacı kapsamaktadır ve toksikolojik tarama testlerinin büyük bir çoğunluğunda olduğu gibi, değişmeden atılan ilaçların idrardan tayinine dayanmaktadır $(32-38)$. 
Zehirlenme etkeninin idrardan izolasyonu için Amberlit XAD-2 ekstraksiyon tekniğinin kullanılması, sıv1-sıv1 ekstraksiyon tekniğinde karşılaştığımız, fazla hacimde çözücü gereksinimi, emülsiyon oluşması ve ekstraksiyon veriminin ortamın pH'sına önemli derecede bağlılığı gibi zorlukları ortadan kaldırmaktadır. Örneğin, morfin ekstraksiyonunda, XAD-2 ve sıvı-sıvı ekstraksiyon yöntemlerinde pH'nın önemini karşılaştıran bir çalışmada, pH 3-12 arasında XAD-2 ekstraksiyonunda \% 50-\% 95 arasında, sıv1-sıv1 ekstraksiyonunda ise \% $1-\% 95$ arasında değişen verimler elde edilmiştir (39). Görüldüğü gibi sıv1-sıvı ekstraksiyon tekniğinde, pH değişimleri, verimi $\% \quad 1^{\prime}$ e kadar düşürmektedir. Ayrıca, XAD-2 ekstraksiyonu, yüksek verim elde edilmesi, kısa zamanda netice alınması ve maliyetinin ucuz olması gibi üstünlükleri nedeniyle toksikolojik tarama testleri için uygun bir ekstraksiyon yöntemidir. XAD-2 ekstraksiyonu, sıv1-sıvı ekstraksiyonu ve protein çöktürme yöntemlerini karşılaştıran bir çalışmada da, XAD-2 ekstraksiyonunda, diğer ikisine göre yüksek verim elde edildiği bildirilmiştir (40).

Tarama yöntemimizde, daha kısa zamanda sonuç almak üzere tek pH'da ekstraksiyon amaçlanmıştır. Asit, bazik ve nötral özellikteki ilaçların tek pH'da ekstraksiyonlarını gerçekleştirebilmek için 5 ayrı pH'da yapılan adsorpsiyon verim çalışmaları sonucu pH 6.5 ortak ve en uygun pH olarak seçilmiştir. Bu pH'da adsorpsiyon verimleri \% $81-\% 95$ arasında bulunmuştur. Ancak aspirin için bu değer $\%$ 50'dir. Tek pH'da XAD-2 ile ekstraksiyona dayalı tarama yöntemlerinin çoğunda $(36-38,41,42)$ pH 8.5 ve üzerindeki pH'lar kullanılmıştır. Bu pH'larda ise asit özellikteki ilaçların, örneğin aspirin ve fenobarbitalin adsorpsiyon veriminin \% 40'a kadar düştüğü görülmektedir (Şekil 3). Kullberg ve ark.'da (43) fenobarbitalle yaptıkları adsorpsiyon verimi çalışmalarında benzer neticeler elde etmişlerdir.

İlaçların idrardan XAD-2 ile ekstraksiyonunda, elüsyon çözücüsünün seçimi amacıyla çeşitli polaritelerde çözücü karışımları denenmiştir. Etil asetat/metanol (1:1) ve kloroform/izopropanol (3:1) çözücü karışımları ile, polaritelerinin fazlalığı nedeniyle, fazlaca safsızlık içeren ekstraktlar elde edilmiştir. Daha az polar olan etil asetat/ 1,2- dikloroetan (3:2) çözücü karışımı ile daha temiz ekstraktlar elde edildiği için, bu çözücü karışımı elüsyon çözücüsü 
olarak seçilmiştir. Neticede ekstraksiyon veriminin gaz sıvı kromatografisi ile nicel tayini çalışmalarında oldukça yüksek değerler elde edilmiştir. Bu değerler adsorpsiyon verimleri ile karşılaştırılırsa, elüsyondaki kaybın fazla olmadığı görülür.

XAD-2 ekstraksiyon yöntemi ile idrardan izole ettiğimiz zehirlenme etkenlerini tanımak için, her analiz laboratuvarı koşulunda uygulanabilecek, duyar, basit ve maliyeti ucuz bir yöntem olan I.T.K. seçilmiştir. Neticede test kapsamındaki ilaçların duyarlık sınırları $0.5 \mu \mathrm{g} / \mathrm{ml}-1.0 \mu \mathrm{g} / \mathrm{ml}$ arasında saptanmıştır. Yöntemimizde akut zehirlenme olaylarında teşhis amaçlandı̆̆ 1 için, test kapsamında olan çeşitli maddelerin, çeşitli vücut sıvılarındaki toksik konsantrasyonları (44-47) göz önüne alındığında İ.T. K. 'nin bu amaç için yeter duyarlıkta olduğu görülebilir.

Daha önce de belirtildiği gibi tarama yöntemimizde çabuk sonuca ulaşmak için İ. T.K.' da tek çözücü sistemi kullanma ve tek plak üzerinde renk belirteçleri birbirinin ardısıra püskürtülerek tanıma amaçlanmıştır. Çalışmalarımız sonucu etil asetat/metanol/ amonyak (85:10:5) çözücü karışımı, test kapsamındaki 21 ilacı en iyi ayıran çözücü sistemi olarak bulunmuştur. Renk belirteçlerinin birbiri ardısıra püskürtülmesiyle 21 ilaç ayrı ayrı saptanmıştır. Tablo II incelendiğinde görüleceği gibi birbirine yakın Rf'deki maddeler renk belirteçleri ile farklı lekeler vermekte ve birbirlerinden kolayca ayrılmaktadir.

Hastanelerde akut ilaç zehirlenmelerinde, ilk yardım ve belirtilere yönelik tedavinin yanısıra, zehirlenme etkeninin tayini için toksikolojik analiz laboratuvarlarının kurulması ülkemizde ivedilikle uygulanmasi gereken bir konudur.

Sonuç olarak, idrardan başka diğer biyolojik sıvılara da uygulanabilir olan tarama yöntemimiz, doğrulayıcı testlerle de desteklenerek bu gereksinmeyi karşılayabilecek niteliktedir.

ÖZET

Sağlık ve Sosyal Yardım Bakanlığı Ankara Numune Hastanesi'nde bir yıllık acil servis başvuruları taranarak zehirlenme olgularının, başvuruların \% 4.98'ini kapsadığ 1 bulunmuştur. Zehirlenme olgu- 
larının \% 63.6'sını ilaç zehirlenmeleri oluşturmaktadır. İlaç zehirlenmelerinden elde edilen veriler göz önüne alınarak seçilen 21 ilacı kapsayan toksikolojik bir tarama testi kurulmuştur. İdrardan izolasyonda kullandı̆̆ımız Amberlit XAD-2 ekstraksiyon tekniğinin standardizasyonu için reçinede adsorpsiyon ve elüsyon koşulları incelenmiştir. Bulgularımız sonucu, pH 6.5, ortak pH olarak seçilmiş ve bu pH'da adsorpsiyon verimleri \% 81 - \% 95 arasinda bulunmuştur. Elüsyon çözücüsü olarak etil asetat / 1,2 dikloroetan (3:2) çözücü karışımı seçilmiş ve gaz sıvı kromatografisi ile yapılan nicel verim tayini çalışmalarında ekstraksiyon verimleri \% 73.4-\% 79.9 olarak bulunmuştur. Zehirlenme etkeninin ekstraksiyondan sonra nitel tayini için yapılan İ.T.K. çalışmalarında, tek bir çözücü sistemi ve tek plak üzerinde, renk belirteçleri püskürtülerek tanıma gerçekleştirilmiştir.

\section{S U M M A R Y}

The record of emergency service admissions at the Numune Hospital Ankara, has been investigated for one year and of the emergency admissions, $4.98 \%$ were cases of poisoning. Of these, $63.6 \%$ were due to drugs. In the light of our observations, a toxicological screening test for 21 drugs was designed. The adsorption conditions of the drugs on the resin and their elutions were investigated in order to standardize the Amberlite XAD-2 extraction method which was used for the isolation of the drugs in the urine samples. On the basis of results obtained, $\mathrm{pH} 6.5$ was selected as the optimum pH. At this $\mathrm{pH}$ value, the adsorption yields were found to be between $81 \%-95 \%$. Ethyl acetate 1,2- dichloroethane $(3: 2)$ was selected as elution solvent. Gas liquid chromatography was used for recovery determinations and their extraction yields were found to be $73.4 \%$ $79.9 \%$. In the TLC studies used in the qualitative determination of the toxic agents extracted, a single solvent system on a single plate with sequentially sprayed colour reagents were used.

\section{L İ T E R A T Ü R}

1- Micik, S., Temle, A., EMS Systems Design and Implementation System Response to The Poisoned Patient. Symposium on Clinical Toxicology, Denver, Colorado (1977)- 
2- Sağlık ve Sosyal Yardım Bakanlığı, Türkiye Sağlık İstatistik Yıllığı 1975-1978, Başbakanlık Basımevi, Ankara (ig8o).

3- Loomis, T.A., Essantials of Toxicology, 2 nd Ed., Lea and Febiger, Philadelphia (1974)-

4- Arena, J.M., Poisoning: Toxicology, Symptoms, Treatments, 4 th Ed., Charles C Publisher, Springfield Illinois (1979).

5- Cami, J., Frati, M., Martin, M., Clin. Toxicol., 17, 421-428 (1980).

6- Volans, G.N., Mitchell, G.M., Proudfoot, A.T., Shanks, R.G., Woodcock, J.A., Br. Med. J., 282, 1613-1615 (1981).

7- Stewart, R.B., Forgnone, M., May, F.E., Forbes, J., Cluff, L.E., Clin. Toxicol. 7, $513-530$ (1974)-

8- Walberg, C.B., Lundberg, G.D., Pantlik, V.A., J. Chromatogr. Sci., 12, 225-227 (1974)-

9- Cravey, R.H., Reed, D., Sedgwick, P.R., Turner, J.E., Clin. Toxicol., 10, 327339 (1977)-

10- Bailey, D.N., Guba, J.J., J. Anal. Toxicol., 3, 133-136 (1979).

11 - Bailey, D.N., Manoguerra, A.S., Ibid, 4, 199-203 (1980).

12- Poklis, A., Ganther, G.E., Clin. Toxicol., 18, 141-147 (1981).

13- Müftü, Y., Çocuk Sağgl̆ğı Hast. Derg., 18, 78-79 (1975).

14- Aykaç, M., İ. U. Tip Fak Mecm. 40, 856-867 (1977).

15- Tokgöz, M., Doğan, F., Keskin, M., E.Ü. Tip Fakültesi Dergisi, 20, 681-696 (1981).

16- Clarke, E.G.C., Isolation and Identification of Drugs, 2 nd Ed., The Pharmaceutical Press, London (1971).

17- Kaistha, K.K., J. Pharm. Sci., 61, 655-678 (1972).

18- Sohn, D., Simon, J., Clin. Chem., 18, .405-409 (1972).

19- Spratt, E., Interfering compounds in urine screening for drugs, "Toxicology Annual 1974" de, Ed. C.L. Winek, Sayfa 229-267, Marcel Dekker Inc., New York (1975).

20 - Fritz, J.S., Tateda, A., Anal. Chem., 40, 2115-2119 (1968).

21 - Davidow, B., Petri, N.L., Quame, B., Amer. J. Clin Pathol, 50, 714-719 (1968)

22 - Sunshine, I., Handbook of Analytical Toxicology, The Chemical Rubber Co., Cleveland, Ohio (1969).

23- Karakaya, A., Türkiye'de S1k Olarak Zehirlenmelere Neden Olan İlaç ve Pestisit lerin XAD-2 ile İdrardan İzolasyon Koşullarının Araştırılması ve Bir Toksikolojik Analiz Tarama Yönteminin Geliştirilmesi, Doktora Tezi, Ankara Üniversitesi Eczac1lık Fakültesi, Ankara (1982).

24 - Lawson, A.A.H., Mitchell, I., Br. Med. J., 4, 153-156 (1972). 
25-Smith, A.J., Ibid., 4, 157-159 (1972).

26- Sipahioğlu, H., Organik Fosfor Zehirlenmelerinde İnsanlarda Görülen Klinik, Elektrokardiyografin ve Anatomik Değişiklikler ve Bunların Köpeklerde Deneysel Olarak Araştırılması, TÜB İTAK VI. Bilim Kongresi Tıp Araştırma Grubu Tebliğleri, Ankara (1977).

27- Murphy, S.D., Pesticides "Casarett and Doull's Toxicology The Basic Science of Poisons, 2 nd Ed. "da, Ed. J. Doull, G.D. Klaassen, M.O. Amdur, Sayfa 357-408, Macmillan Publishing Co. Inc., New York (1980).

28 - Matthew, H., Proudfoot, A.T., Brow, S.S., Aitken, R.C.B., Br. Med. J., 3, 489-493 (1969)-

29 - Lundberg, G.D., Walberg, C.B., Pantlik, V.A., Clin. Chem., 20, 121-125 (1974).

30 - Tompsett, S.L., Analyst, 93, 740-748 (1968).

31 - Dusci, L.J., Hackett, L.P., Clin. Toxicol., 14, 587-593 (1979).

32- Mule, S.J., Bastos, M.L., Jucofsky, D., Saffer, E., J. Chromatogr., 63, 289-301 (1971)-

33 - Weissman, N., Lowe, M.L., Beattie, J.M., Demetriou, J.A., Clin. Chem., 17, 875881 (1971).

34 - Kuliberg, M.P., Gorodetzky, C.W., Ibid, 20, 177-183 (1974).

35- Pranitis, P.A.F., Milzoff, J.R., Stolman, A., J. Forensic Sci., 19, 917-926 (1974).

36- Bogusz, M., Gierz, J., Bialka, J., Arch. Toxicol., 41, 153-162 (1978).

37 - Wahl, K., Rejent, T., J. Anal. Toxicol., 3, 216-217 (1979).

38- Elahi, N., Ibid, 4, 26-30 (1980).

9 - Miller, W.L., Kuliberg, M.P., Banning, M.E., Brown, L.D., Doctor, B.P., Biochem. Med., 7, 145-158 (1973).

40 - Missen, A.W., Lewin, J.F., Clin. Chim. Acta, 53, 389-390 (1974).

41 - İbrahim, G., Andryauskas, S., Bastos, M.L., J. Chromatogr., 108, 107-116 (1975).

42 - Başaran, N., Hıncal, F., Doğa Bilim Dergisi: Tip, 6, 5-12 (1982).

43 - Kullberg, M.P., Miller, W.L., McGowan, F.J., Doctor, B.P., Biochem. Med., 7, 323-335 (1973)-

44 - Weissman, N., Lowe, M.L., Beattie, J.M., Demetriou, J.A., Clin. Chem., 17, 875 -881 (1971).

45 - Baselt, R.C., Wright, J.A., Cravey, R.H., Ibid., 21, 44-62 (1975).

46 - Wallace, J.E., Blum, K., Singh, J.M., The determination of drugs in biological specimens, "Toxicology Annual 1974" de, Ed. C.L. Winek, Sayfa 167-185, Marcel Dekker Inc., New York (1975).

47- Winek, C.L., Drug and chemical blood levels, "Toxicology Annual 1974" de, Ed. C.L. Winek. Sayfa 203-228, Marcel Dekker Inc., New York (1975). 